\title{
Pengaruh Brainwriting Berbasis Learning Management System (LMS) Terhadap Kemampuan Menulis Teks Eksposisi Siswa
}

\author{
Riza Aprilia Utama, Dedi Kuswandi, Saida Ulfa \\ Fakultas IImu Pendidikan, Universitas Negeri Malang
}

\section{Edcomtech}

Jurnal Kajian

Teknologi Pendidikan

Volume 6, No 1, April 2021

$1-12$

Submitted 04-05-2020

Accepted 15-05-2020

Corresponding Author

Riza Aprilia Utama

rezatama90@gmail.com

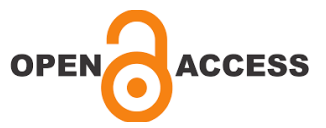

\begin{abstract}
Abstrak
Penelitian ini mengaplikasikan model Brainwriting berbasis learning Management System (LMS) terhadap peserta didik kelas X SMK Ma'arif Kota Batu untuk membuktikan efektifitasnya pada pembelajaran menulis karangan teks eksposisi. Metode penelitian yang digunakan adalah eksperimen (Quasi Experimental Design). Desain yang diaplikasikan termasuk dalam nonequivalent control group design Posttest Only Control Group Design (POCGD) dengan sampel sebanyak 40 orang yang terbagi menjadi dua kelompok, ( $X$ $R P L)$ sebagai kelompok eksperimen dan (X-TO2) sebagai kelompok kontrol. Instrumen penelitian menerapkan tes tulis untuk mengukur hasil belajar menulis karangan teks eksposisi. Uji statistik alpha Cronbach, Kolmogorov-Smirnov, Levene Statistic, independent t-test yang diberdayakan dalam penelitian ini. Hasil uji statistik independent $t$ test oleh 2 penilai menunjukkan Sig. (2-tailed) sebesar 0.000 dengan kesimpulan ditolak dan diterima. Dengan begitu dapat disimpulkan ada pengaruh dengan diterapkannya model brainwriting berbasis LMS terhadap kemampuan menulis karangan teks eksposisi.
\end{abstract}

Kata kunci: Model Brainwriting, LMS, Teks Eksposisi

\begin{abstract}
This research applied the brainwriting modellearning ManagementSystem(LMS)based on students in class X SMK Ma'arif Kota Batu to prove its effectiveness in learning to write exposition text. The study method used is experimental (QuasiExperimental Design). The design applied was included in the non-equivalent control group design Posttest Only Control Group Design (POCGD) with a sample of 40 people divided into two groups. X-RPL as an experiment group and X-TO2 as a control group The research instrument applied a written test to measure learning outcomes write essays text exposition. Cronbach's alpha statistic test, Kolmogorov-Smirnov, Levene Statistics, independent t-test were used in this study. The results of the independent $t$-test statistic test by 2 assessors showed Sig. (2-tailed) of 0,000 with the conclusion that is rejected and is accepted. Thus it can be concluded that there is an influence by the implementation of the LMSbased brainwriting model on the ability to write essays text exposition.
\end{abstract}

Keywords: brainwriting model, LMS, Exposition text. 


\section{LATAR BELAKANG}

Era abad 21 seringkali disebut sebagai era dimana informasidapat dengan mudah didapat melalui teknologi. Pada era ini, masyarakat telah mengenal berbagai tren seperti busana, musik dan lain sebagainya (Az-Zahroh et al., 2019) sehingga dengan adanya perkembangan tersebut. Teknologi informatika di dorong untuk terintegrasi dengan dunia Pendidikan agar dunia Pendidikan dapat selaras dengan kemajuan dalam dunia teknologi dan informasi, hal itu selaras dengan karakteristik pembelajaran abad 21 yang ditandai dengan dunia Pendidikan yang sudah harus serba otomatis. Dalam konteks pemanfaatan teknologi informatika pada dunia Pendidikan dapat dibuktikan dengan terbatasnya "ruang dan waktu" yang menjadikan efisiensi dan kemudahan mengakses ilmu pengetahuan tanpa memperhatikan ruang dan waktu (Badan Standar Nasional Pendidikan, 2010). Selain itu pembelajaran abab 21 (P21) ditandai juga dengan (1) mudahnya mendapat informasi tanpa memperhatikan ruang, dan waktu; (2) komputerisasi yang semakin canggih; (3) dan pekerjaan yang mulai mengarah ke otomatisasi; (4) komunikasi yang tidak terbatas sehingga bisa melakukan komunikasi tanpa memperhatikan ruang, dan waktu (Litbang Kemdikbud, 2013).

Pendidikan abad 21 mengembangkan kerangka pembelajaran yang sesuai dengan perkembangan abad 21. Kerangka pembelajaran tersebut menginginkan peserta didik memiliki Subjek Inti dan Pembelajaran abad 21 (Core Subject and 21 $1^{\text {st }}$ Century Themes), kemampuan hidup dan berkarir (Life and Career Skills), kemampuan belajar dan berinovasi (Learning and Innovation Skills) dan media informasi dan kemampuan berteknologi (Information Media, and Technology Skills). Kerangka ini menjabarkan tentang kemampuan, keahlian dan pengetahuan yang harus dimiliki oleh peserta didik agar dapat menjalani kehidupan dan pekerjaan yang semakin kompleks (Lee \& Hung, 2012).

Salah satu kerangka pembelajaran abad 21 yang dikembangkan untuk peserta didik adalah Learning and Innovating skills yang didalamnya mencakup 4Cs, yaitu (a) Creativity
\& Innovation Skills, ini menginginkan peserta didik mampu mengembangkan kreativitas untuk menghasilkan berbagai terobosan dan inovasi (Mednick, 1962); (b) Critical Thinking \& Problem Solving, ini menginginkan peserta didik mampu berpikir kritis dalam menyusun dan mengungkapkan, secara lateral, dan sistematik ketika memecahkan suatu masalah (Ennis, 2015); (c) Communication, ini menginginkan peserta didik mampu menelaah, memproses, dan memproduksi kegiatan berkomunikasi secara baik. Baik itu secara lisan, tulis, atau multimedia (American Speech Language Hearing Association, 2014); dan (d) Collaboration, ini menginginkan peserta didik dapat berkolaborasi dengan teman sejawat atau orang yang lebih tua sehingga dapat berkolaborasi dan menciptakan solusi dalam suatu masalah (Lai, 2011). Keempat kemampuan ini wajib dikuasai agar dapat menghadapi P21. Sehingga hal ini memunculkan tantangan tersendiri di dalamnya (Lai \& Viering, 2012). Salah satu kegiatan pembelajaran bahasa Indonesia yang dapat memfasilitasi 4 Cs adalah keterampilan menulis.

Keterampilan menulis merupakan keterampilan bahasa non lisan yang digunakan ketikapenuturinginberkomunikasisecaratidak langsung. Keterampilan menulis seharusnya ditingkatkan karena keterampilan bahasa non lisan ini sangat penting untuk mebangun dasar yang kuat dalam keterampilan berbahasa dan mengembangkan keterampilan 4Cs peserta didik. Menulis adalah keterampilan produktif yang tidak akan pernah bisa diabaikan oleh siapapun yang memiliki cita-cita yang tinggi. Namun sekarang peserta didik lebih banyak mengalami kesulitan ketika diminta untuk merancang gagasan dan argumen, menggunakan gaya penulisan yang tepat dan menghadirkan sebuah ekspresi dalam menuangkan sebuah ide (Hasan, 2015; Sangamitra \& Mohamed, 2016; Togatorop, 2015). Pada umumnya menulis adalah keterampilan yang rumit dan sulit untuk dikuasai, namun kendati begitu bukan berarti keterampilan menulis harus diabaikan begitu saja, karena keterampilan menulis dapat mengembangkan pola pikir peserta didik sehingga secara tidak langsung mendorong 
peserta didik untuk lebih berpikir kritis. Hal ini disebabkan keterampilan menulis tidak hanya bagaimana seseorang menyampaikan aspirasinya dengan sebuah tulisan namun keterampilan menulis membuat bagaimana seorang penulis dapat menuangkan gagasan, merangkai kosa kata kalimat atau mengorganisasikan paragrafnya dengan tepat sehingga tidak membuat bingung pembaca dan pembaca dapat mengetahui isi hati seorang penulis.

Rendahnya produktivitas kemampuan menulis telah terbukti dengan adanya penelitian yang dilakukan oleh winarti yang dijelaskan pada (jurnal penelitian Bahasa volume 1 tahun 2018, hlm. 96) yang menyatakan bahwa keterampilan menulis peserta didik SMA di kota bandung masih kurang. Berdasarkan data yang dikumpulkan, siswa SMA di kota bandung sudah bisa menjabarkan karangan namun belum bisa mengorganisasikan karangan dengan baik dan penjabarannya juga masih terbatas. Mereka juga belum bisa menyusun kalimat dengan baik sehingga apa yang mereka tulis masih sulit dipahami oleh pembaca dan belum mendapatkan esensi atau apa yang ingin disampaikan oleh penulis (Aini, 2018).

Teks eksposisi termasuk bagian kecil yang ada dalam pelajaran bahasa indonesia namun karangan teks eksposisi penting untuk peserta didik. Teks eksposisi merupakan suatu pengembangan pola paragraf dalam kemampuan menulis yang isinya merupakan gagasan, memberikan penjelasan tentang penggunaan gaya penulisan singkat dan padat sehingga dapat dengan mudah dipahami. Teks eksposisi merupakan salah satu teks yang memfasilitasi peserta didik untuk menuangkan suatu gagasan dengan tujuan agar peserta didik dapat mengungkapkan ideidenya yang dimulai dengan pernyataan awal dilanjutkan dengan argumen dan ditutup dengan reiteration (penegasan ulang). Teks eksposisi memiliki manfaat yang banyak untuk peserta didik, seperti, meningkatkan critical thinking, mengumpulkan dan menjabarkan sebuah informasi sesuai dengan pendapat pribadi, dan memperluas cakrawala (Kurnia, 2016; Suryana, 2017).

Brainwriting merupakan model pembelajaran yang diproyeksikan khusus untuk meningkatkan kemampuan menulis. Sehingga model tersebut sangat sesuai untuk pelajaran bahasa indonesia khususnya pada materi menulis karangan teks eksposisi. Brainwriting diproyeksikan untuk membantu peserta didik mengembangkan suatu ide ataupun topik untuk dikonversikan menjadi sebuah bentuk teks pendek. Model ini juga diproyeksikan untuk mendorong peserta didik yang minim berkontribusi karena takut memaparkan ide-ide secara lisan, dengan cara menggunakan bahasa non lisan sehingga mereka bisa berkontribusi dengan sumbangsih ide dengan peserta didik lain. Model pembelajaran brainwriting diciptakan untuk membantu menghasilkan ide-ide atau gagasan terhadap suatu topik dalam waktu singkat.

Untuk menunjang Model pembelajaran brainwriting agar dapat berkontribusi secara maksimal maka kita harus menggunakan Learning Management System (LMS). LMS adalah sebuah pirantilunakyang diproyeksikan untuk memfasilitasi pembelajaran secara daring. Sampai saat ini banyak produk LMS yang digunakan, peneliti mengembangkan sendiri produk LMS yang ingin digunakan yaitu sistem informasi pembelajaran dan akademik atau dapat disebut dengan SIPEKAD. SIPEKAD adalah sistem web yang dirancang khusus untuk mengolah data, menyimpan data, dan melaksanakan proses pembelajaran sehingga dalam satu sistem web sekolah dapat mengatur sistem akademik dan melakukan proses pembelajaran secara terintegrasi online untuk menunjang pembelajaran yang efektif dan dapat menciptakan pembelajaran yang bermakna. Dalam SIPEKAD terdapat laman SIPEKAD Learning yaitu suatu laman yang digunakan untuk kegiatan pembelajaran daring, yang didalamnya terdapat modul pembelajaran, Uji Kompetensi dan video penunjang pembelajaran.

\section{METODE}

Sejalan dengan tujuan penelitian, jenis penelitian yang akan dilakukan merupakan penelitian kuantitatif. Dikatakan sebagai penelitian kuantitatif, karena data yang akan diproses merupakan angka-angka. Angka- 
angka yang diproses didapat dari hasil menulis karangan teks eksposisi peserta didik kelas X SMK MA'ARIF KOTA BATU setelah menggunakan model brainwriting. Data berupa skor didapat dari hasil tes peserta didik. Penelitian kuantitatif sendiri merupakan penelitian yang data penelitiannya berupa Angka, data tersebut bisa diperoleh melalui pengumpulan, penafsiran dan penampilan hasil data tersebut yang kemudian dianalisis menggunakan statistik (Arikunto, 2014; Sugiyono, 2019)

Sedangkan desain penelitian yang diaplikasikan termasuk dalam nonequivalent control group design Posttest Only Control Group Design (POCGD). Desain ini menggunakan dua kelompok satu kelompok dijadikan sebagai kelompok kontrol dan satunya dijadikan sebagai kelompok eksperimen yang dipilih secara random. Kelompok Kontrol memiliki fungsi sebagai pembeda, sedangkan kelompok eksperimen sebagai kelompok yang telah diberikan tindakan selama kurun waktu tertentu (Latipun, 2017; Sugiyono, 2019). Desain penelitian akan dijabarkan pada Tabel 1.

Tabel 1. Desain penelitian

\begin{tabular}{lccc}
\hline Kelompok & Prates & Tindakan & Posttest \\
\hline $\begin{array}{l}\text { Kelompok } \\
\begin{array}{l}\text { Eksperimen } \\
(\text { E) }\end{array}\end{array}$ & - & $\mathrm{X}_{1}$ & $\mathrm{Y}_{1}$ \\
\hline $\begin{array}{l}\text { Kelompok } \\
\text { Kontrol (K) }\end{array}$ & - & $\mathrm{X}_{1}$ & $\mathrm{Y}_{1}$ \\
\hline
\end{tabular}

Keterangan:

$\mathrm{X}_{1}=$ Tindakan pada kelompok eksperimen yang menerapkan model Brainwriting.

$\mathrm{X}_{1}=$ Tindakan pada kelompok kontrol yang menerapkan model Problem Based Learning (PBL)

$Y_{1}$ dan $Y_{2}=$ Tes Akhir (posttest) yang didapat dari kedua kelompok (E\&K).

Kita dapat melihat efektifitas atau pengaruh dari variabel bebas pada variabel terikat, dengan cara melihat perbedaan rata-rata hasil menulis karangan teks eksposisi posttest kelompok eksperimen () dan kelompok kontrol (). Apabila terdapat perbedaan hasil mean dalam menulis karangan teks eksposisi antara kedua kelompok, dimana hasil mean menulis karangan teks eksposisi pada kelompok eksperimen Lebih tinggi dibandingkan dengan hasil mean menulis karangan teks eksposisi pada kelompok kontrol, maka kita dapat menarik kesimpulan penerapan yang diberikan mempunyai pengaruh terhadap perubahan yang terjadi pada variabel terikat.

\section{Teknik Analisis Data}

\section{Uji Reliabilitas antar Penilai}

Uji reliabilitas merujuk pada suatu pengertian bahwa suatu instrumen yang baik adalah instrumen yang dapat dipercaya untuk digunakan sebagai alat mengumpulkan data (Zohrabi, 2013). Data hasil kinerja menulis teks eksposisi dalam penelitian ini akan dinilai dua orang yaitu guru Bahasa Indonesia dan peneliti. Hasil penilaian dari dua orang tersebut pasti berbeda. Maka, perlu dilakukan uji reliabilitas antar penilai untuk mengetahui tingkat kesamaan mereka dalam memberikan penilaian. Uji reliabilitas antar penilai diolah dengan menggunakan bantuan program IBM SPSS versi 25 dengan alpha Cronbach. Pengujian ini sebagai syarat apakah data hasil penelitian akan data dilanjutkan untuk ke tahap pengujian selanjutnya atau tidak. Hasil penghitungan data akan dicocokkan dengan table kriteria Guilford untuk menginterpretasikan derajat reliabilitasnya. adapun pedoman inteprestasi derajat reliabilitas Guilford ditunjukkan dalam Tabel 2.

Tabel 2. Kriteria Koefisien Reliabilitas Hasil Penelitian

\begin{tabular}{|c|c|c|}
\hline $\begin{array}{l}\text { Koefisien } \\
\text { korelasi }\end{array}$ & Korelasi & Interpretasi reliabilitas \\
\hline$r<0.20$ & $\begin{array}{l}\text { Sangat } \\
\text { Rendah }\end{array}$ & $\begin{array}{l}\text { Sangat tidak tepat / } \\
\text { Sangat tidak baik }\end{array}$ \\
\hline $\begin{array}{l}0.20 \leq r< \\
0.40\end{array}$ & Rendah & Tidak tepat / Buruk \\
\hline $\begin{array}{l}0.40 \leq r< \\
0.70\end{array}$ & Sedang & $\begin{array}{c}\text { Cukup tepat / Cukup } \\
\text { baik }\end{array}$ \\
\hline $\begin{array}{l}0.70 \leq r< \\
0.90\end{array}$ & Tinggi & Tepat / Baik \\
\hline $\begin{array}{l}0.90 \leq r< \\
1.00\end{array}$ & $\begin{array}{l}\text { Sangat } \\
\text { Tinggi }\end{array}$ & $\begin{array}{c}\text { Sangat tepat / Sangat } \\
\text { baik }\end{array}$ \\
\hline
\end{tabular}




\section{Uji Normalitas Data}

Uji normalitas data dilakukan pada posttest kedua kelompok (E\&K). Tujuan diadakannya Uji Normalitas data untuk mengobservasi apakah sebaran data yang dikumpulkan berdistribusi normal atau tidak karena jumlah data penelitian 40 dan tidak dikelompokkan, maka peneliti menggunakan metode KolmogorovSmirnov dan Shapiro-Wilk. Menurut Lestari dan yudhanegara (2015:243), pengambilan keputusan dilakukan jika taraf nyata $a=5 \%$ $(0.05)$ < nilai a Sig, maka data berdistribusi normal.

Hipotesis pengambilan keputusan uji normalitas;

$\mathrm{H}_{0}$ : Nilai didapat dari populasi yang berdistribusi normal

$\mathrm{H}_{\mathrm{a}}$ : Nilai didapat dari populasi yang tidak berdistribusi normal

Pengambilan keputusan adalah sebagai berikut:

$\mathrm{H}_{0}$ akan ditolak jika nilai Sig $<a$, dengan $a=$ $5 \%(0.05)$

$\mathrm{H}_{0}$ akan diterima jika nilai Sig $>a$, dengan $a$ $=5 \%(0.05)$

\section{Uji Homogenitas Data}

Pengujian ini dilakukan pada posttest kedua kelompok (E\&K). Pengujian ini dilakukan untuk mengetahui apakah data pada kedua kelompok (E\&A) memiliki varian data sama atau tidak. Data dinyatakan homogen atau memiliki varians yang sama apabila nilai Sig $>0,05$ Hipotesis pengambilan keputusan homogenitas adalah sebagai berikut.

$\mathrm{H}_{0}$ : varians nilai kemampuan menulis kedua kelompok homogen

$\mathrm{H}_{\mathrm{a}}$ : varian nilai kemampuan menulis kedua kelompok tidak homogen

Pengambilan keputusan adalah sebagai berikut:

Jika nilai Sig $<a$, maka ditolak, dengan $a,=$ $5 \%(0.05)$

Jika Sig $>a$, maka akan diterima dengan $a,=$ $5 \%(0.05)$

Uji-t
Uji-t diaplikasikan untuk mengetahui signifikansi perbedaan nilai mean data posttest pada kedua kelompok (E\&K). Taraf nyata pada uji-t ini sebesar $a=5 \%(0.05)$

Hipotesis yang akan diuji adalah sebagai berikut:

$\mathrm{H}_{0}$ : Tidak ditemukan perbedaan yang penting antara kedua kelompok (E\&K) dalam menulis karangan teks eksposisi

$\mathrm{H}_{a}$ : Ditemukan perbedaan yang penting antara kedua kelompok (E\&K) dalam menulis karangan teks eksposisi

Kriteria pengambilan keputusan jika nilai probabilitas (Sig) > 0.05 maka diterima dan jika nilai probabilitas (Sig) $\leq 0.05$ maka ditolak.

\section{Uji Mann Whitney U}

Jika syarat pengujian parametrik tak dapat dipenuhi, maka uji hipotesis penelitian akan dilakukan menggunakan Uji Mann Whitney $U$, pendapat tersebut sesuai dengan yang dijelaskan (Lestari \& Yudhanegara, 2015) yang menyatakan uji tersebut digunakan untuk menganalisis statistik terhadap dua sampel independen bebas apabila jenis data yang akan dianalisis berskala ordinal atau normal, atau data tersebut tidak berdistribusi normal. Hipotesisnya akan diuji sebagai berikut

$\mathrm{H}_{0}$ : Tidak ditemukan perbedaan yang penting antara kedua kelompok (E\&K) dalam menulis karangan teks eksposisi

$\mathrm{H}_{\mathrm{a}}$ : Ditemukan perbedaan yang penting antara kedua kelompok (E\&K) dalam menulis karangan teks eksposisi

Kriteria pengambilan keputusan adalah jika nilai P-value atau Asymp Sig. (2-tailed) > 0,05 maka diterima dan jika nilai $\mathrm{P}$-value $\leq 0,05$ maka ditolak.

\section{HASIL \& PEMBAHASAN Hasil}

Subyek dalam penelitian dibedakan menjadi dua, yaitu kelas X-RPL sebagai kelompok eksperimen yang diterapkannya model Brainwriting berbasis LMS dan kelas X-TO-2 sebagai kelompok kontrol yang diterapkannya model Problem Based Learning. Data yang diproses dalam penelitian ini adalah hasil mean menulis karangan teks eksposisi dari kedua kelompok (E\&A). Instrumen yang digunakan untuk 
posttest kelompok eksperimen dan kelompok kontrol adalah sama, yaitu instrumen tes peserta didik. Dalam penelitian ini peneliti memberikan satu pernyataan yang masingmasing akan disampaikan kepada kelompok eksperimen dan kelompok kontrol yaitu "kita sudah mengetahui bahayanya egoisme manusia yang merusak ekosistem alam sekitar tapi pernahkah kita memikirkan apa yang kita lakukan saat ini itu merugikan kata di masa hadapan oleh karena itu saya ingin kalian membuat teks eksposisi dengan tema Eco vs Ego agar kita dapat mengetahui dampak dari apa yang kita perbuat sekarang!

Sebelum dilakukannya pengambilan hipotesis terhadap data yang didapat dari kemampuan menulis karangan teks eksposisi. Peneliti melakukan uji prasyarat analisis data untuk mengetahui apakah data itu layak untuk digunakan sebagai pengambilan keputusan terhadap hipotesis atau tidak.

\section{Uji Reliabilitas}

Uji reliabilitas ini dilakukan untuk mengetahui tingkat kesamaan antara dua penilai dalam memberikan penilaian. Uji reliabilitas antar penilai diolah dengan menggunakan bantuan program IBM SPSS versi 25 dengan alpha Cronbach. Pengujian ini sebagai syarat apakah data hasil penelitian akan data dilanjutkan untuk ke tahap pengujian selanjutnya atau tidak.

\begin{tabular}{cc}
$\begin{array}{c}\text { Tabel } 3 \text { Hasil Uji Reliabilitas Dengan } \\
\text { Menggunakan Alpha Cronbach }\end{array}$ \\
\hline \multicolumn{3}{c}{ Reliability Statistik Model Brainwriting } \\
\hline $\begin{array}{c}\text { Cronbach } \\
\text { Alpha }\end{array}$ & $\begin{array}{c}\text { Cronbach Alpha } \\
\text { berdasarkan item } \\
\text { terstandarisasi. }\end{array}$ \\
\hline 934 & .961
\end{tabular}

Reliability Statistik Model Problem Based Learning

\begin{tabular}{ccc}
\hline $\begin{array}{c}\text { Cronbach } \\
\text { Alpha }\end{array}$ & $\begin{array}{c}\text { Cronbach Alpha } \\
\text { berdasarkan item } \\
\text { terstandarisasi. }\end{array}$ & N of Item \\
\hline .681 & .737 & 2
\end{tabular}

Berdasarkan tabel 3 dapat diketahui kesamaan data dari dua penilai untuk hasil kemampuan menulis karangan teks eksposisi yang menggunakan model brainwriting berbasis LMS sangat tinggi dan memiliki interpretasi reliabilitas sangat baik/sangat tepat. Hal itu ditunjukkan dengan Cronbach Alpha berdasarkan item terstandarisasi. sebesar 0,961 sedangkan yang menerapkan Problem Based Learning menunjukkan 0,737 yang memiliki arti korelasi tinggi dan interpretasi reliabilitas baik/tepat. Dengan begitu peneliti dapat menarik kesimpulan hasil penilaian menulis karangan teks eksposisi dari dua penilai (peneliti dan guru bahasa Indonesia) dinyatakan reliabilitas atau data tersebut baik.

\section{Uji Normalitas}

Uji normalitas dilakukan agar kita dapat mengobservasi apakah populasi dari penelitian yang dilakukan berdistribusi normal atau tidak, peneliti menggunakan desain uji Kolmogorov-smirnov test mengaplikasikan IBM SPSS versi 25 untuk uji normalitas. Populasi pada data penelitian yang dilakukan berdistribusi normal jika nilai Asymp.Sig (2-tailed) $>a=5 \%(0.05)$

\section{Tabel 4 Hasil Uji Normalitas}

One-Sample Kolmogorov-Smirnov Test

\begin{tabular}{|c|c|c|c|c|c|}
\hline & & BW P1 & BW P2 & PBL P1 & PBL P2 \\
\hline $\mathrm{N}$ & & 20 & 20 & 20 & 20 \\
\hline \multicolumn{6}{|l|}{ Normal } \\
\hline \multirow{3}{*}{$\begin{array}{l}\text { Para- } \\
\text { meters }\end{array}$} & Mean & 83.2500 & 82.0000 & 64.7500 & 67.0000 \\
\hline & Std. & & & & \\
\hline & $\begin{array}{l}\text { Devi- } \\
\text { ation }\end{array}$ & 6.54438 & 9.09019 & 13.32538 & 8.01315 \\
\hline \multirow{4}{*}{$\begin{array}{l}\text { Most } \\
\text { Extreme } \\
\text { Diffe- } \\
\text { rences }\end{array}$} & & & & & \\
\hline & $\begin{array}{l}\text { Abso- } \\
\text { lute }\end{array}$ & .155 & .129 & .153 & .199 \\
\hline & $\begin{array}{l}\text { Posi- } \\
\text { tive }\end{array}$ & .140 & .129 & .076 & .199 \\
\hline & $\begin{array}{l}\text { Nega- } \\
\text { tive }\end{array}$ & -.155 & -.129 & -.153 & -.141 \\
\hline $\begin{array}{l}\text { Test } \\
\text { Statistic }\end{array}$ & & .155 & .129 & .153 & .199 \\
\hline \multicolumn{6}{|l|}{ Asymp. } \\
\hline $\begin{array}{l}\text { Sig. } \\
\text { (2-tailed) }\end{array}$ & & .200 & .200 & .200 & .038 \\
\hline a. Test d & ibut & is Nor & & & \\
\hline
\end{tabular}


Berdasarkan Tabel 4 Test yang diterapkan pada hasil kemampuan menulis karangan teks eksposisi dapat dijabarkan sebagai berikut:

a. Nilai Brainwriting penilai 1 menunjukkan hasil nilai $\mathrm{Sig}>a$ yaitu $0.200>0.05$ sehingga nilai Brainwriting penilai 1 berdistribusi normal.

b. Nilai Brainwriting penilai 2 menunjukkan hasil Sig > a yaitu $0.200>0.05$ sehingga nilai Brainwriting penilai 2 berdistribusi normal.

c. Nilai Problem Based Learning penilai 1 menunjukkan hasil nilai $\mathrm{Sig}>a$ yaitu $0,200>0,05$ sehingga nilai Problem Based Learning penilai 1 berdistribusi normal. d. Nilai Problem Based Learning penilai 2 menunjukkan hasil nilai $\mathrm{Sig}>a$ yaitu $0,038>0,05$ sehingga nilai Problem Based Learning penilai 1 berdistribusi normal.

\section{Uji Homogenitas}

Uji ini diaplikasikan untuk menentukan apakah nilai peserta didik kelompok eksperimens dan kelompok kontrol homogen (memiliki varians sama). Uji homogenitas diaplikasikan terhadap nilai yang didapat dari penilai 1 dan penilai 2 dalam menulis karangan teks eksposisi. Nilai disebut berdistribusi homogen jika nilai hitung $>0.05$. Untuk menguji homogenitas peneliti menggunakan IBM SPSS versi 25 .

Tabel 5. Hasil Uji Homogenitas

\begin{tabular}{|c|c|c|c|c|c|}
\hline \multicolumn{6}{|c|}{ Test of Homogeneity of Variances } \\
\hline & & $\begin{array}{l}\text { L e ve n e } \\
\text { Statistic }\end{array}$ & df1 & $\mathrm{df} 2$ & Sig. \\
\hline \multirow{4}{*}{$\begin{array}{l}\text { Hasil Menulis Teks } \\
\text { Eksposisi Penilai } 1\end{array}$} & Berdasarkan rata-rata & 6.114 & 1 & 38 & .018 \\
\hline & Berdasarkan Median & 5.436 & 1 & 38 & .025 \\
\hline & $\begin{array}{l}\text { Berdasarkan Median } \\
\text { dan dengan df yang } \\
\text { disesuaikan }\end{array}$ & 5.436 & 1 & 27.216 & .027 \\
\hline & $\begin{array}{l}\text { Berdasarkan rata-rata } \\
\text { yang dipangkas }\end{array}$ & 5.869 & 1 & 38 & .020 \\
\hline \multicolumn{6}{|c|}{ Test of Homogeneity of Variances } \\
\hline & & $\begin{array}{l}\text { Le v e n e } \\
\text { Statistic }\end{array}$ & df1 & df2 & Sig. \\
\hline \multirow{4}{*}{$\begin{array}{l}\text { Hasil Menulis Teks } \\
\text { Eksposisi Penilai } 2\end{array}$} & Berdasarkan rata-rata & .544 & 1 & 38 & .465 \\
\hline & Berdasarkan Median & .830 & 1 & 38 & .368 \\
\hline & $\begin{array}{l}\text { Berdasarkan Median } \\
\text { dan dengan df yang } \\
\text { disesuaikan }\end{array}$ & .830 & 1 & 37.404 & .368 \\
\hline & $\begin{array}{l}\text { Berdasarkan rata-rata } \\
\text { yang dipangkas }\end{array}$ & .552 & 1 & 38 & .462 \\
\hline
\end{tabular}


Hasil penghitungan uji homogenitas varian data hasil menulis karangan teks eksposisi penilai 1 menunjukkan signifikansi 0, 20 dan penilai 2 menunjukkan signifikansi 0,462. Sehingga dapat diambil kesimpulan bahwa data tersebut memiliki varian yang homogen karena signifikansi dari dua penilai > 5\% ( 0.05 ).

\section{Analisis Data}

Merupakan proses atau upaya untuk mengolah data agar dapat mendapatkan data baru sehingga data tersebut lebih mudah dipahami dan diproses. Analisis data pada penelitian ini dilakukan untuk menguji hipotesis yang sudah ditetapkan yaitu mengetahui efektifitas model brainwriting berbasis LMS terhadap kemampuan menulis karangan teks eksposisi. Peneliti melakukan analisis data desain uji-t untuk menguji hipotesisnya.

Tabel 6 hasil analisis data dari dua penilai

\begin{tabular}{|c|c|c|c|c|c|c|}
\hline \multicolumn{7}{|c|}{ Independent Samples t Test } \\
\hline \multicolumn{2}{|c|}{ Levene's Test for Equality of Variances } & \multicolumn{5}{|c|}{ t-test for Equality of Means } \\
\hline & & Sig. & $\mathrm{t}$ & Df & \multicolumn{2}{|c|}{$\begin{array}{l}\text { Sig. } \\
\text { (2-tailed) }\end{array}$} \\
\hline \multirow{3}{*}{$\begin{array}{l}\text { Hasil Menulis Teks } \\
\text { Eksposisi (penilai 1) }\end{array}$} & Equal variances & 6.114 & .018 & 5.573 & 38 & .000 \\
\hline & assumed & & & & & \\
\hline & $\begin{array}{c}\text { Equal variances } \\
\text { not assumed }\end{array}$ & & & 5.573 & 27.662 & .000 \\
\hline \multirow{3}{*}{$\begin{array}{l}\text { Hasil Menulis Teks } \\
\text { Eksposisi (penilai 2) }\end{array}$} & Equal variances & .544 & .465 & 5.536 & 38 & .000 \\
\hline & assumed & & & & & \\
\hline & $\begin{array}{l}\text { Equal variances } \\
\text { not assumed }\end{array}$ & & & 5.536 & 37.411 & .000 \\
\hline
\end{tabular}

Pada tabel 6 kita bisa melihat Hasil posttest menulis karangan teks eksposisi pada kelompok ekspe rimen dan kelompok kontrol oleh penilai 1 dan penilai 2 menunjukkan nilai Sig.(2-tailed) $0.000<5 \%$ ( 0.05 ). Nilai tersebut menunjukkan terdapat perbedaan antara hasil menulis karangan teks eksposisi peserta didik pada kedua kelompok (E\&A). Setelah mendapatkan data dari independent sample $t$ test, maka akan dibuktikannya hipotesis dari penelitian. Untuk Pembuktian hipotesis diambil dari hasil independent sample $t$ test dari penilai 1 dan penilai 2

Pembuktian hipotesis dalam penelitian ini diambil dari hasil independent sample $t$ test, yang didapat dari hasil skor posttest kelompok eksperimen dan kelompok kontrol yang menunjukkan nilai Sig. (2-tailed) sebesar 0.000. data tersebut memperlihatkan bahwa $p<0.05$ yang memiliki arti data tersebut signifikan.

(1) Hipotesis Nol (: "Tidak terdapat perbedaan kemampuan menulis karangan teks eksposisi antara yang menggunakan model Brainwriting berbasis LMS dengan yang menggunakan model Problem Based Learning". Ditolak

(2) Hipotesis Alternatif (: "Terdapat perbedaan kemampuan menulis karangan teks eksposisi antara yang menggunakan model Brainwriting berbasis LMS dengan yang menggunakan model Problem Based Learning". Diterima

\section{Pembahasan}

Penelitian mengenai penerapan model brainwriting terbukti dapat meningkatkan kemampuan menulis peserta didik. Hal itu senada seperti yang disampaikan oleh Irawati (2018) yang menerapkan model brainwriting dengan bantuan media komik untuk menulis kreatif cerita fantasi. Penelitian ini diaplikasikan pada siswa kelas VII SMP Negeri 2 Parongpong. 
Dengan berbantuan media komik peserta didik dapat membuat cerita fantasi berdasarkan imajinasi mereka setelah membaca buku komik yang disediakan oleh pendidik sehingga secara tidak disadari peserta didik melakukan berpikir kritis, mengkritisi komik yang diimplementasikan kedalam sebuah cerita fantasi.

Model Brainwriting dilakukan untuk menghasilkan keberanekaragaman ide atau gagasan. Dengan begitu peserta didik melakukan proses berpikir kritis tanpa mereka sadari dan menemukan banyak ide dari beberapa orang bukan secara individu. Ide-ide itu akan diolah dengan cermat sehingga akan menghasilkan ide yang baru. Model ini diproyeksikan untuk mendorong semua anggota kelompok ikut andil dalam pembuatan ide dan mengaitkan ide satu dengan ide yang lain, secara tidak langsung model ini dapat memaksimalkan pemroduksian ide (Michalko, 2004; Paulus \& Nijstad, 2003).

Hal serupa juga disampaikan oleh Ramadhan \& Kasmansyah (2018) yang menerapkan pelajaran menulis puisi dengan menerapkan model brainwriting. Menurut rahmat dengan diterapkannya model brainwriting dapat membantu peserta didik menemukan ide yang baru untuk menulis puisi sehingga peserta didik dapat membuat puisi dari pengembangan ide yang sudah di dapat dari diskusi bersama teman teman.

Choi, Jeon, Park, \& Nah (2018) juga menjelaskan dalam penelitianya inovasi baru tercipta dari keadaan dimana ide-ide dapat meluap sebanyak mungkin. Dengan penerapan brainwriting diharapkan mampu menjadi metode yang efektif untuk mencapai inovasi terbuka.

Kemampuan menulis merupakan kemampuan wajib yang harus dikuasai oleh peserta didik karena menulis merupakan tingkatan tertinggi dan paling sulit dibandingkan dengan menyimak dan membaca. Menulis merupakan komponen yang penting untuk dunia Pendidikan. Karena dengan menulis dapat memudahkan para peserta didik untuk berpikir kritis tanpa mereka sadari (Chaedar \& Alwasilah, 2007; Tarigan, 2008). Menulis merupakan penyampaian pesan kepada pembaca. Jika sebuah tulisan tidak dapat memberikan pemahaman kepada pembaca maka tulisan tersebut akan sia-sia. Pembelajaran menulis adalah mengajarkan seseorang untuk menyampaikan aspirasinya dengan bahasa non lisan sehingga dapat membantu orang orang introvert untuk menuangkan ide kedalam sebuah tulisan dengan tujuan agar dapat berkomunikasi dengan mudah dan membuat orang lain memahami kita tanpa kita menggunakan bahasa lisan oleh karena itu menulis bergantung dengan pembaca (reader-dependent) dan kualitas sebuah tulisan berhasil atau tidak untuk menyampaikan informasi itu ditentukan dengan respon pembaca. Oktavia, Martono, \& Wartiningsih (2019) menerangkan dalam penelitianya bahwa menulis merupakan hal yang penting karena dengan menulis peserta didik dapat mencurahkan apa yang dia rasakan tanpa menggunakan bahasa lisan.

Menggunakan model brainwriting untuk meningkatkan kemampuan menulis sangatlah akurat hal itu disebabkan karena model brainwriting dikhususkan untuk menciptakan banyak ide dalam waktu singkat, karena itu model ini sangat cocok jika diterapkan dalam pembelajaran menulis karangan teks eksposisi karena teks karangan eksposisi merupakan suatu bentuk retorika yang berusaha untuk mengklarifikasi, mendidik, menguraikan atau menerangkan serta mengevaluasi tentang tema yang memiliki tujuan memperluas cakrawala seorang pembaca (Chaedar \& Alwasilah, 2007; Keraf, 2009; Suparno \& Yunus, 2003).

Peneliti mengembangkan model brainwriting dengan mengintegrasikannya dengan LMS. Learning Management System atau lebih sering dikenal dengan LMS. Perangkat ini termasuk dari perangkat lunak yang digunakan untuk proses edukasi secara daring. Dalam kesempatan ini peneliti mengembangkan LMS sendiri yang diberi nama SIPEKAD (Sistem Informasi Pembelajaran dan Akademik). SIPEKAD merupakan sebuah management system yang diproduksi khusus untuk manajemen informasi sekolah, data sekolah serta dipergunakan untuk kegiatan pembelajaran daring yang dikemas berbasis web. 
Pentingnya mengintegrasi metode pembelajaran dengan LMS juga dijelaskan Kabassi et al (2016) dalam penelitiannya yang menjelaskan penggunaan platform dapat meningkatkan materi pendidikan dengan cara mengintegrasi video materi pembelajaran yang interaktif. Penerapan model brainwriting berbasis LMS sendiri lebih mudah dipahami dan diterapkan pada era pembelajaran abad 21 ini karena pada era ini mudahnya mengakses informasi menuntut semua serba otomatis. berikut Langkah-langkah yang harus diperhatikan untuk mengaplikasikan model pembelajaran brainwriting berbasis LMS dalam pembelajaran meliputi: (1) Pendidik membagi peserta didiknya menjadi beberapa kelompok (2) pendidik dan peserta didik mendiskusikan materi pelajaran yang sudah di unggah pada LMS. (3) Peserta didik diberi waktu 5-10 menit untuk menulis ide-ide dari tema yang sudah dibahas. (4) Meminta anggota lain membaca ide-ide yang sudah di tulis (5) Peserta didik diminta memberi saran tambahan ide pada lembar yang sudah ditulis teman. (6) Memilah ide-ide yang paling bagus untuk dijadikan draft Tulisan (Asih, 2014; Oviansha, 2015)

Penelitian yang mengaplikasikan model brainwriting berbasis LMS akan diterapkan pada mapel bahasa Indonesia materi karangan teks eksposisi. Kelas X-RPL Sebagai kelompok eksperimen mendapatkan model brainwriting berbasis LMS sebagai metode pengajarannya. Langkah-langkah yang diterapkan dalam Brainwriting berbasis LMS sangat membantu peserta didik untuk membuat karangan teks eksposisi. Hal itu dikarenakan model brainwriting berbasis LMS menggunakan langkah-langkah yang mudah sehingga dapat diikuti dengan baik oleh peserta didik. Dengan diterapkannya model brainwriting berbasis LMS membantu peserta didik dapat dengan mudah membuka materi sebelumnya tentang struktur dan kaidah karangan teks eksposisi untuk dipelajari lebih dalam. Selain itu peserta didik juga dapat bertukar ide atau gagasan dengan teman tanpa takut merasa salah atau disalahkan dengan begitu peserta didik dapat lebih mudah dalam mengembangkan draft yang nantinya akan disusun sebagai karangan teks eksposisi. Sedangkan kelas X-TO-2 sebagai
Kelompok kontrol mendapat perlakuan menulis karangan teks eksposisi menerapkan model Problem Based Learning. Model ini lebih menjurus ke problem solving namun model ini kurang tepat jika diaplikasikan untuk pembelajaran menulis karangan teks eksposisi walaupun langkah langkah yang diterapkan sama dengan model brainwriting hal itu disebabkan karena model ini lebih mengutamakan ide atau gagasan secara individu dan pandangan siswa terhadap suatu masalah itu sendiri bukan dari ide dan gagasan yang dipadukan dengan orang lain. Untuk pengintegrasianya berbeda model yang diterapkan pada kelompok eksperimen menggunakan web based learning yang terintegrasi pada LMS yang diciptakan peneliti. Sedangkan pada kelompok kontrol diintegrasikan dengan discovery learning yang menggunaan LCD proyektor dalam pengaplikasianya.

Hasil kemampuan menulis karangan teks eksposisi Antara kedua kelompok (E\&A) Memiliki perbedaan yang penting. perbedaan yangmencolokterlihatdarisegipengembangan gagasan dan struktur kebahasaan dalam karangan teks eksposisi. Peserta didik yang menggunakan model brainwriting cenderung dapat mengembangkan gagasan dengan baik bahkan pengembangan idenya lebih lengkap dibandingkan dengan kelompok kontrol yang terkesan monoton dalam mengembangkan gagasannya. Hal itu dikarenakan pada kelompok eksperimen peserta didik dapat bertukar ide dengan teman satu kelompok sehingga ide yang tidak dapat terpikirkan oleh individu dapat terpenuhi dengan ide dari teman satu kelompok, sedangkan pada kelompok kontrol peserta didik fokus mengembangkan ide secara individu itu yang menyebabkan gagasan yang disampaikan terasa monoton dan hampir sama semua. Untuk segi struktur karangan teks eksposisi peserta didik kelompok eksperimen memiliki struktur yang lengkap dan sistematis terdiri dari tiga bagian yaitu tesis, argumentasi dan kesimpulan. Sedangkan pada kelompok kontrol strukturnya masih ambigu antara tesis, argumentasi dan kesimpulan hal itu disebabkan kelompok eksperimen dapat dengan mudah melihat catatan tentang 
struktur teks pada web based learning sedangkan kelompok kontrol tidak dapat melihat struktur secara lengkap yang ditulis pada catatannya.

\section{SIMPULAN}

Kesimpulan dari penelitian ini didapat dari penjabaran penulis tentang hasil kemampuan menulis karangan teks eksposisi yang telah dijabarkan pada hasil dan pembahasan. Sehingga dapat disimpulkan sebagai berikut: Jika dibandingkan kemampuan menulis karangan teks eksposisi peserta didik yang menerapkan model brainwriting berbasis LMS dengan yang menerapkan model problem based learning lebih baik kemampuan peserta didik yang menggunakan model brainwriting berbasis LMS karena peserta didik yang menggunakan brainwriting berbasis LMS dapat berkolaborasi dengan teman dalam mencari ide dan gagasan. Oleh sebab itu terdapat perbedaan yang penting dalam hal kemampuan dalam menulis karangan teks eksposisi peserta didik. Perbedaan tersebut dapat dibuktikan dengan hasil uji-t independent sample $t$ test pada hasil posttest kedua kelompok (E\&K) yang dinilai oleh dua penilai yang memiliki Sig. (2-tailed) yang sama yaitu sebesar 0.000 pada taraf signifikansi 5\% (0.05).sehingga Nilai Sig. (2-tailed) < 0,05 itu membuktikan bahwa kemampuan menulis karangan teks eksposisi peserta didik yang menggunakan brainwriting berbasis LMS lebih baik dari pada yang menggunakan problem based learning.

\section{REFERENSI}

Aini, W. (2018). Pemanfaatan "Audiobook Teman Imaji" Untuk Mendukung Kemampuan Literasi Tingkat Lanjut: Studi Tindakan Eksperimental terhadap Peserta Didik Kelas VII-B SMPN 28 Bandung. Universitas Pendidikan Indonesia.

American Speech Language Hearing Association. (2014). International communication project 2014. Retrieved from Www. Communication2014, Com.

Arikunto, S. (2014). Prosedur Penelitian: Suatu Pendekatan Praktik. Jakarta:
Rineka Cipta.

Asih. (2014). Strategi pembelajaran Bahasa Indonesia. Bandung: Pustaka Setia.

Az-Zahroh, S. F., Thaariq, Z. Z. A., Surahman, E., Widyasari, C. M., Qolbi, M. S., \& Diana, R. C. (2019). Developing Ethic Game (Ethnomathematics Game): The Instructional Media of Culture Mathematics with Tringo by Ki Hadjar Dewantara. JPP (Jurnal Pendidikan Dan Pembelajaran), 26(2), 43-50.

Badan Standar Nasional Pendidikan. (2010). Paradigma pendidikan nasional abad XXI. Jakarta: BSNP.

Chaedar, A., \& Alwasilah, S. S. (2007). Pokoknya Menulis. Bandung: Kiblat Buku Utama.

Choi, H., Jeon, Y., Park, H., \& Nah, K. (2018). Collaborative workshop between client and agency for open innovation. Journal of Open Innovation: Technology, Market, and Complexity, 4(1), 13.

Ennis, R. H. (2015). Critical thinking: A streamlined conception. In The Palgrave handbook of critical thinking in higher education (pp. 31-47). Springer.

Hasan, H. (2015). Kendala yang dihadapi guru dalam proses belajar mengajar matematika di SD Negeri Gani Kabupaten Aceh Besar. Jurnal Pesona Dasar, 1(4).

Irawati. (2018). Model Brainwriting Berbantuan Media Komik Tanpa Teks Dalam Pembeajaran Menulis Kreatif Cerita Fantasi Siswa Kelas VII SMP Negeri 2 Parongpong Kabupaten Bandung Barat Tahun Ajaran 2018/2019. Seminar Internasional Riksa Bahasa, 1033-1042.

Kabassi, K., Dragonas, I., Ntouzevits, A., Pomonis, T., Papastathopoulos, G., \& Vozaitis, Y. (2016). Evaluating a learning management system for blended learning in Greek higher education. SpringerPlus, 5(1), 101.

Keraf, G. (2009). Diksi dan gaya bahasa. Gramedia Pustaka Utama.

Kurnia, K. (2016). Penerapan Model Problem Based Learning untuk Meningkatkan Kemampuan Menulis Teks Eksposisi pada Siswa Kelas $X$ lis-4 SMA Negeri 8 Makassar. Pepatudzu: Media 
Pendidikan Dan Sosial Kemasyarakatan, 9(1), 72-84.

Lai, E. R. (2011). Collaboration: A literature review (Vol. 11). Pearson Publisher.

Lai, E. R., \& Viering, M. (2012). Assessing 21st Century Skills: Integrating Research Findings. Pearson, 67.

Latipun. (2017). Psikologi Eksperimen. Malang: UMM Press.

Lee, S.-S., \& Hung, D. (2012). Is There an Instructional Framework for 21st Century Learning? Creative Education, 3(4), 461-470.

Lestari, K. E., \& Yudhanegara, M. R. (2015). Penelitian pendidikan matematika. Bandung: PT Refika Aditama.

Litbang Kemdikbud. (2013). Kurikulum 2013: Pergeseran paradigma belajar abad-21. Jakarta: Kemdikbud.

Mednick, S. (1962). The associative basis of the creative process. Psychological Review, 69(3), 220.

Michalko, M. (2004). Permainan Berpikir (Thinkertoys). Bandung: Remaja Rosdakarya.

Oktavia, W., Martono, M., \& Wartiningsih, A. (2019). Penerapan Teknik Brainwriting Untuk Meningkatkan Menulis Wacana Narasi Pada Siswa Kelas Xi Tphp Smk. Tanjungpura University.

Oviansha, M. (2015). Teaching Writing by Combining Brain Writing Strategy And Quick Write Strategy for Senior High School Students". Gramatika. Retrieved from http://www.jurnal. stkippgrisumbar.ac.id/
Paulus, P. B., \& Nijstad, B. A. (2003). Group creativity: Innovation through collaboration. Oxford University Press.

Ramadhan, R., \& Kasmansyah, K. (2018). Pengaruh Model Pembelajaran Brain Writing Terhadap Kemampuan Menulis Puisi Siswa Kelas VIII SMP Negeri 13 Palembang. Logat: Jurnal Bahasa Indonesia Dan Pembelajaran, 5(2), 181192.

Sangamitra, A., \& Mohamed, S. H. (2016). Developing the writing skills in English of Students at College Level-AProcess Approach. International Journal of Applied Engineering Research, 11(1), 40-43.

Sugiyono. (2019). Metode Penelitian Pendidikan (Kuantitatif, Kualitatif, Kombinasi, R\&D dan Penelitian Pendidikan). Bandung: Alfabeta.

Suparno, \& Yunus, M. (2003). Keterampilan Dasar Menulis. Jakarta: Pusat Penerbitan Universitas Terbuka.

Suryana, S. (2017). Permasalahan mutu pendidikan dalam perspektif pembangunan pendidikan. Edukasi, 2(1).

Tarigan, H. G. (2008). Menulis sebagai keterampilan berbahasa. Bandung: Angkasa.

Togatorop, E. (2015). Teaching writing with a web based collaborative learning. International Journal of Economics and Financial Issues, 5(1S).

Zohrabi, M. (2013). Mixed Method Research: Instruments, Validity, Reliability and Reporting Findings. Theory \& Practice in Language Studies, 3(2). 